\title{
PETROGENESIS OF CU-NI SULPHIDE ORES FROM O'OKIEP AND KLIPRAND, NAMAQUALAND, SOUTH AFRICA: CONSTRAINTS FROM CHALCOPHILE METAL CONTENTS
}

\author{
W.D. MAIER \\ Department of Geosciences, University of Oulu 90014, Finland \\ e-mail: wolfgang.maier@oulu.fi \\ M.A.G. ANDREOLI \\ South African Nuclear Energy Corporation, South Africa; School of Geosciences, University \\ of the Witwatersrand, Johannesburg 2000, South Africa \\ e-mail: marco.andreoli@necsa.co.za \\ D.I. GROVES \\ Centre for Exploration Targeting, University of Western Australia, Crawley 6009, Australia \\ e-mail: di_groves@hotmail.com
}

\section{S.-J. BARNES}

Department of Sciences de la Terre, Université du Québec à Chicoutimi, Chicoutimi G7H 2B1, Canada e-mail: sjbarnes@uqac.ca

(C) 2012 December Geological Society of South Africa

\begin{abstract}
The petrogenesis of sulphide ores in the O'okiep district has remained controversial. Based mainly on the concentration of chalcophile metals (PGE, $\mathrm{Cu}, \mathrm{Ni}$ ), it is proposed that the sulphides segregated from a basaltic magma generated during melting of sub-continental lithospheric mantle. Sulphide saturation of the magma was delayed due to relatively high $f \mathrm{O}_{2}$ until crustal contamination occurred during the advanced stages of differentiation. The immiscible sulphide melt was entrained and fractionated in dynamic magma conduits. Sulphides enriched in monosulphide solid solution (mss) component precipitated at depth in the Kliprand area of southern Namaqualand to form the Hondekloof deposits, whereas the O'okiep ores crystallised at shallower levels from highly fractionated residual sulphide liquids enriched in intermediate solid solution (iss). Sulphides of intermediate composition occur at Ezelsfontein. In the context of this model, the O'okiep intrusions could represent the proximal magmatic members of an IOCG suite of deposits, raising the prospect for additional IOCG deposits elsewhere in southern Africa. The model also predicts an enhanced potential at O'okiep for undiscovered Ni sulphide ores at depth.
\end{abstract}

\section{Introduction}

Since the middle of the 19 th Century and until the recent closure of the Carolusberg mine, the sulphide ores in the Springbok area of Namaqualand, also known as the O'okiep Copper District (Figure 1), have been a major source of copper for South Africa (cf. McIver et al., 1983; Lombaard et al., 1986; Schoch and Conradie, 1990; Cawthorn and Meyer, 1993; Clifford et al., 1995; 2012; Van Zwieten et al., 1996; 2004; Robb et al., 1999; Duchesne et al., 2007). The mineralisation is hosted by the orthopyroxenitic and, to a lesser extent, noritic and dioritic portions of composite mafic-ultramafic pipeand dyke-like bodies of the Koperberg Suite. One of the main reasons for the profusion of research papers written on the Koperberg Suite is the atypical nature of the ores compared to most magmatic sulphide ores from elsewhere, namely their unusually high $\mathrm{Cu} / \mathrm{Ni}$ and $\mathrm{Cu} / \mathrm{S}$ ratios, and the abundance of bornite among the sulphide minerals. This has led to controversy on the origin of the Koperberg suite and its ores, with some authors calling for a crustal progenitor (Clifford et al., 1995; 2004; Maier, 2000; Duchesne et al., 2007), whereas most others invoke contamination of mantle magmas by crustal anatectic melts (McIver et al., 1983; Cawthorn and Meyer, 1993; Van Zwieten et al., 1996; Robb et al., 1999).

In the present study, aimed at providing some further constraints on the genesis of the Koperberg suite, noble metal data are presented from several deposits in the Springbok area, including $\mathrm{Cu}$-rich ores from Carolusberg, East O'okiep, West O'okiep, Rietberg, Spektakel, Hoits, Homeep, Jubilee, and Nigramoep (Figure 1). New geochemical data are also presented from more Ni-rich ores at Ezelsfontein, also in the Springbok area, and from the apparently co-genetic Hondekloof deposit, situated near the village of Kliprand, ca. $120 \mathrm{~km}$ southeast of the O'okiep district (Figure 1; Taylor 1990; Andreoli and Moore 1991; Hamman et al., 1995; Andreoli et al., 2006).

\section{The Koperberg Suite}

\section{Geographic distribution and emplacement age}

For more than a century the predominantly mafic bodies of the Koperberg Suite were thought to occur only in the 

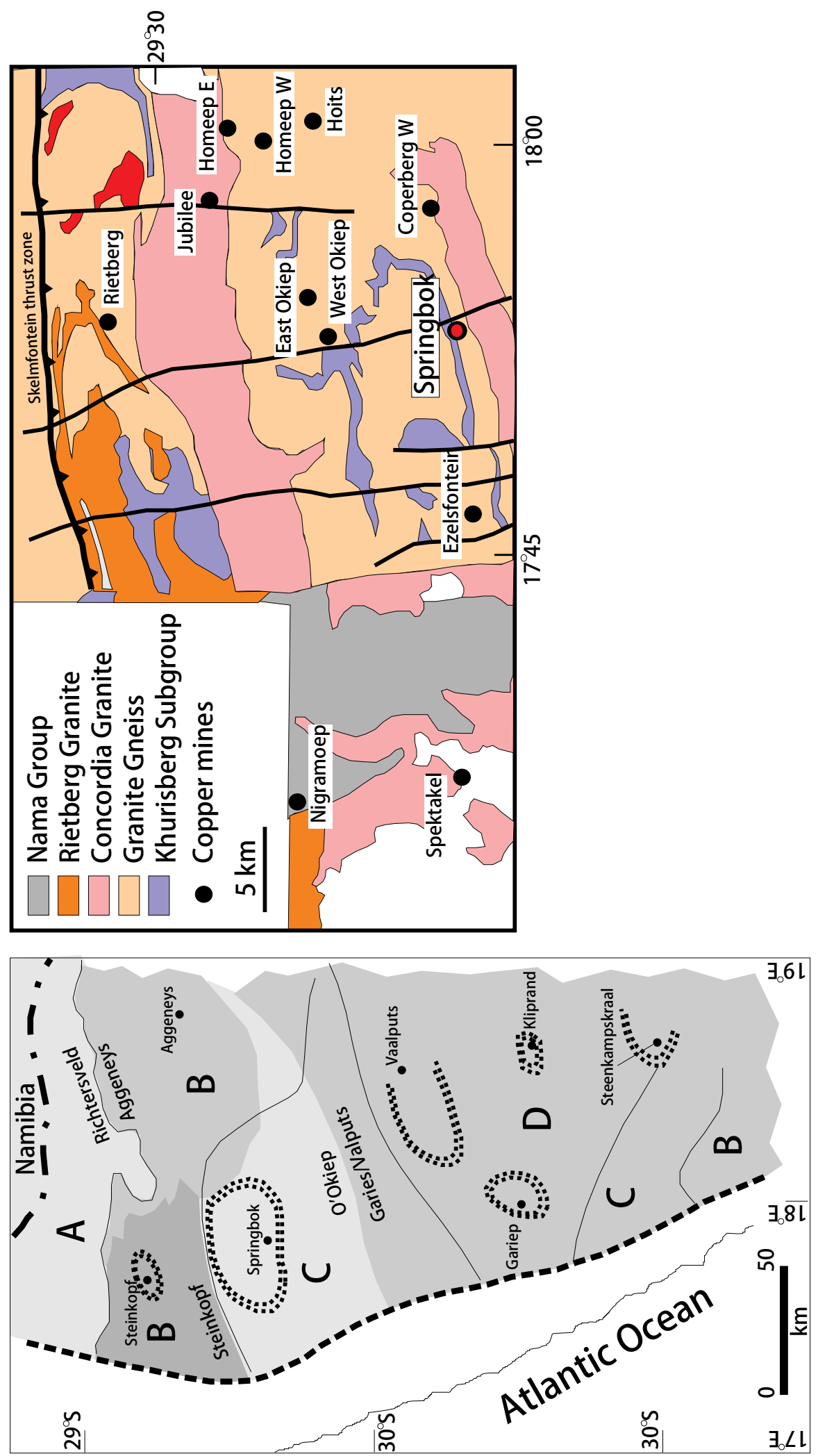

Figure 1. (a) Geological sketch of western Namaqualand showing localities mentioned in the text (modified after Waters, 1989; Andreoli et al., 2006). Tectonic terranes are shown in variable shade, double dotted lines indicate clusters of Koperberg suite and related rocks, and solid lines show metamorphic facies boundaries (A: greenschist, B: amphibolite, C: low-T granulite, D: high-T granulite), short broken line near coastline: staurolite zone (Pan African overprint) (b) Geology and locality map of the O'okiep area. 

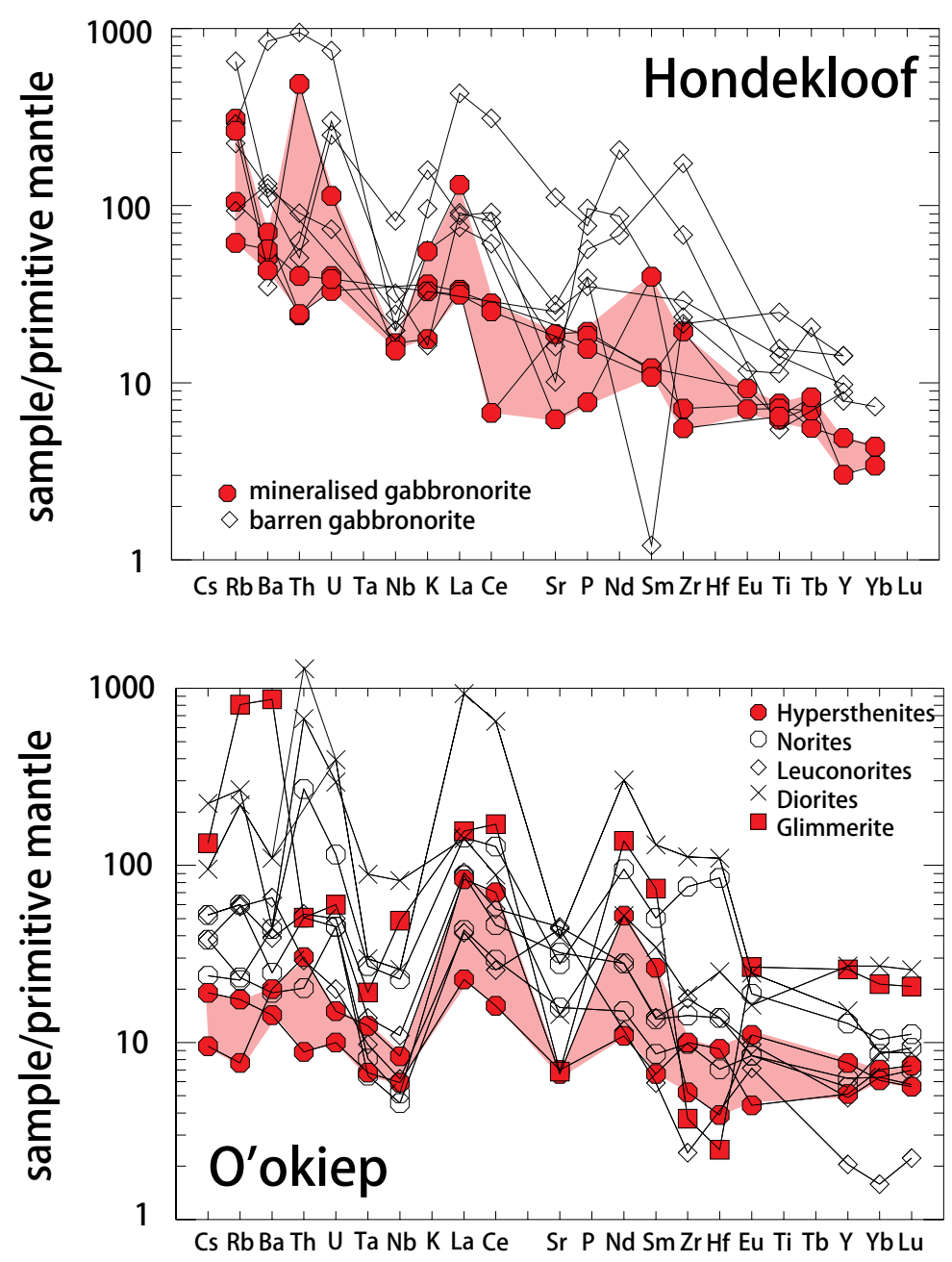

Figure 2. Mantle normalised multi-element diagram of incompatible trace elements, for rocks from (a) Hondekloof, and (b) O'okiep (data from Duchesne et al., 2007). Normalization values from Sun and McDonough (1989).

O'okiep Copper District, a relatively restricted area in northern Namaqualand where they intrude the orthogneisses, granitoids and granulites of the 1200 to 1000 Ma Namaqualand Metamorphic Complex (McIver et al., 1983; Lombaard et al., 1986; Cawthorn and Meyer 1993; Van Zwieten et al., 1996; Clifford et al., 1995; 2004; 2012). The emplacement age has consistently been difficult to resolve from the age of regional metamorphism, with recent work establishing a range between $\sim 1040$ and $\sim 1020 \mathrm{Ma}$, indistinguishable from a lower granulite facies metamorphic peak dated at $\sim 1030 \mathrm{Ma}$ (P $\sim 5$ kbars, $\mathrm{T} \sim 750$ to $800^{\circ} \mathrm{C}$; Robb et al., 1999; Clifford et al., 1995; 2004 and references therein).

Since the late 1980s, detailed mapping in central and southern Namaqualand brought to light other clusters of intrusive rocks with many of the lithological, geochemical, emplacement age, and structural features distinctive of the Koperberg Suite near Springbok
(Figure 1; Andreoli et al., 1986; 1994; 2006; Hamman et al., 1996; Read et al., 2002). This southern region experienced upper granulite facies conditions characterized by the stability of such rare minerals like osumilite, as well as spinel + quartz ( $>$ >5 kbars, $\mathrm{T} \sim 860$ to $1000^{\circ} \mathrm{C}$; Mouri et al., 2003; Robb et al., 1999). These articles also note some significant differences between clusters, namely in their Sm-Nd model ages, in the relative proportions of rock types, and their metallogenic signature. Copper was the main resource in the O'okiep District, replaced respectively by magnetite/ ilmenite near Vaalputs, monazite + copper at Steenkampskraal, and nickel near Kliprand.

\section{Field relations and litbologies}

The Koperberg Suite in the Springbok area is represented by more than 1700 irregular and discontinuous sheet-, plug-, pipe- and dyke-like intrusive 
Table 1. Compositional data from Okiep district and Hondekloof.

\begin{tabular}{|c|c|c|c|c|c|c|c|c|c|c|c|c|c|c|c|c|c|}
\hline & Rocktype & $\mathbf{B a}$ & Sr & $\mathbf{Y}$ & $\mathrm{Cr}$ & $\mathbf{N i}$ & $\mathbf{v}$ & $\mathbf{C u}$ & $\mathbf{S}$ & $\mathbf{R u}$ & $\mathbf{R h}$ & Pd & Ag & Os & Ir & $\mathbf{P t}$ & Au \\
\hline \multicolumn{18}{|l|}{ Cu-rich ores } \\
\hline \multicolumn{18}{|l|}{ Carolusberg } \\
\hline Cw1905 & Orthopyroxenite & 59 & 24 & 14 & 3534 & 791 & 358 & 48796 & 1.27 & & & 93.0 & & & 1.7 & 96.0 & 173.0 \\
\hline cw2662 & Norite & 108 & 471 & 48 & 692 & 241 & 280 & 18508 & 0.88 & & & 44.0 & & & 0.5 & & 76.3 \\
\hline $\mathrm{cw} 271$ & Norite & 117 & 381 & 64 & 1125 & 331 & 445 & 23904 & 0.82 & 2.0 & 0.6 & 29.0 & & & 0.2 & 13.2 & 50.5 \\
\hline cw276 & Norite & 106 & 292 & 85 & 1413 & 382 & 508 & 31386 & 0.80 & 2.4 & 1.0 & 44.8 & & & 0.3 & 19.8 & 60.6 \\
\hline cw293 & Norite & 197 & 687 & 48 & 595 & 171 & 281 & 13407 & 0.36 & & & 25.0 & & & $<0.05$ & & 74.4 \\
\hline cw508 & Orthopyroxenite & 20 & 10 & 14 & 3210 & 767 & 256 & 55470 & 1.78 & & & & & & 0.8 & & 285.0 \\
\hline \multicolumn{18}{|l|}{ East Okiep } \\
\hline $\mathrm{e} 02$ & Leuconorite & 992 & 699 & 23 & 34 & 172 & 216 & 10225 & 1.25 & 2.5 & & 5.9 & & & 0.1 & & 20.9 \\
\hline $\mathrm{e} 03$ & Leuconorite & 867 & 746 & 17 & 45 & 100 & 227 & 9990 & 1.12 & 3.5 & & & & & 0.1 & & 21.4 \\
\hline $\mathrm{e} 06$ & Leuconorite & 242 & 629 & 35 & 38 & 83 & 248 & 12264 & 1.26 & 3.4 & & 5.4 & & & $<0.05$ & 9.0 & 23.2 \\
\hline $\mathrm{e} 08$ & Leuconorite & 256 & 650 & 31 & 29 & 83 & 210 & 13294 & 1.47 & & & 7.0 & & & $<0.05$ & & 27.5 \\
\hline \multicolumn{18}{|l|}{ Jubilee } \\
\hline j102 & Pyroxene diorite & 177 & 476 & 42 & 1568 & 457 & 185 & 22600 & 0.81 & 3.8 & 1.1 & 36.9 & & & 0.5 & 34.3 & 55.2 \\
\hline j186 & Mica diorite & 1192 & 787 & 13 & 0 & 38 & 333 & 100 & 0.00 & 4.8 & & 5.6 & & & 0.1 & & 1.6 \\
\hline j23 & Pyroxene diorite & 367 & 349 & 70 & 909 & 233 & 157 & 5300 & 0.32 & 4.3 & 0.5 & 20.5 & & 0.6 & 0.2 & 12.6 & 16.3 \\
\hline $\mathrm{j} 28$ & Mica diorite & 725 & 698 & 58 & 31 & 16 & 176 & 500 & 0.01 & 5.4 & & 2.8 & & & $<0.05$ & & 0.3 \\
\hline$j 53$ & Pyroxene diorite & 264 & 765 & 10 & 488 & 215 & 294 & 12800 & 0.46 & 3.1 & 0.5 & 8.0 & & & 0.1 & 10.1 & 9.4 \\
\hline j64 & Pyroxene diorite & 199 & 673 & 11 & 21 & 58 & 275 & 600 & 0.11 & 2.9 & 0.3 & & & & $<0.05$ & 1.3 & 0.5 \\
\hline \multicolumn{18}{|l|}{ West Okiep } \\
\hline w02 & Leuconorite & 293 & 626 & 50 & 324 & 396 & 711 & 41663 & 1.12 & & 1.0 & & & & 0.1 & & 177.8 \\
\hline w04 & Leuconorite & 251 & 667 & 37 & 436 & 434 & 572 & 42628 & 1.40 & 6.7 & 4.9 & & & & 1.6 & & 157.4 \\
\hline w06 & Leuconorite & 252 & 644 & 54 & 371 & 209 & 863 & 9140 & 0.30 & 2.1 & & 2.5 & & & $<0.05$ & 6.4 & 21.4 \\
\hline \multicolumn{18}{|l|}{ Hoits } \\
\hline U-190-275 & Leuconorite & 455 & 126 & 60 & 191 & 224 & 597 & 24960 & 2.56 & 3.3 & & 10.0 & & & 0.1 & & 36.0 \\
\hline U-II-230 & Leuconorite & 1811 & 365 & 43 & 178 & 174 & 623 & 20750 & 1.17 & 4.0 & 0.5 & 6.0 & & & 0.1 & & 24.0 \\
\hline \multicolumn{18}{|l|}{ Spektakel } \\
\hline NW 103124 & Norite & 32 & 156 & 25 & 396 & 347 & 438 & 39820 & 3.66 & 2.0 & 0.8 & 22.0 & & 1.1 & 0.2 & 13.0 & 1.5 \\
\hline NW 103103 & Norite & 102 & 130 & 20 & 163 & 108 & 337 & 9261 & 0.87 & 1.7 & & 5.0 & & & $<0.05$ & 3.0 & 1.9 \\
\hline \multicolumn{18}{|l|}{ Rietberg } \\
\hline $\mathrm{R}-1$ & Mica diorite & 233 & 85 & 41 & 1165 & 490 & 673 & 64830 & 3.18 & 23.9 & 0.9 & 34.4 & 29.0 & & 0.2 & 57.0 & 151.9 \\
\hline R-2 shaft & Mica diorite & 1045 & 161 & 145 & 5297 & 582 & 1098 & 42230 & 1.49 & 5.0 & & 37.0 & 11.0 & & 0.3 & 14.0 & 92.5 \\
\hline \multicolumn{18}{|l|}{ Нотеер } \\
\hline Homeep east u-86 & Leuconorite & 1494 & 211 & 135 & 1196 & 164 & 632 & 13900 & 0.76 & 4.5 & 0.5 & 33.0 & & & 0.4 & 57.2 & \\
\hline Homeep west 2 & Cu-ore & 72 & 374 & 0 & 65 & 1175 & 21 & 118700 & 7.30 & 33.1 & 0.4 & 331.0 & 92.0 & & 0.2 & 686.0 & 233.2 \\
\hline Homeep west 1 & Leuconorite & 167 & 172 & 576 & 3579 & 1375 & 1517 & 67280 & 5.73 & 9.2 & & 63.0 & 4.0 & & 0.1 & 62.0 & 143.8 \\
\hline \multicolumn{18}{|l|}{ Nigramoep } \\
\hline D1 & Semi-massive $\mathrm{Cu}$ ore & 165 & 370 & 17 & 5040 & 512 & 1578 & 142400 & 6.52 & 17.0 & & 22.0 & 106.0 & & 0.1 & 115.0 & 251.8 \\
\hline 28651.8 & Semi-massive $\mathrm{Cu}$ ore & 67 & 316 & 12 & 1088 & 362 & 948 & 160900 & 8.52 & 20.8 & & 30.0 & 28.0 & & 0.2 & 32.0 & 5.7 \\
\hline 8164.3 & Leuconorite & 1865 & 500 & 17 & 172 & 73 & 260 & 11950 & 0.50 & 3.0 & & 9.0 & & & 0.1 & & 12.3 \\
\hline 8177 & Norite & 170 & 463 & 11 & 827 & 224 & 352 & 11180 & 0.91 & 4.0 & 0.6 & 33.0 & & 0.5 & 0.1 & & 33.9 \\
\hline KNU286 48 & Semi-massive $\mathrm{Cu}$ ore & 235 & 232 & 8 & 1335 & 564 & 1474 & 92550 & 4.23 & 10.0 & & 40.0 & 7.0 & & 0.2 & & 30.8 \\
\hline
\end{tabular}

Intermediate ores

\section{Ezelsfontein}

i-26

I-35 $\begin{array}{llllllllllll}\text { Plag-mica-ap-sulf rock } & 33 & 105 & 170 & 1516 & 1882 & 935 & 12700 & 15.20 & 1.9 & 1.8 & 16.0\end{array}$

$\begin{array}{llllllllllll}\text { Plag-mica-ap-sulf rock } & 111 & 95 & 143 & 1876 & 1219 & 1169 & 2172 & 11.10 & 0.0 & 0.8 & 30.0\end{array}$ $\begin{array}{ll}0.7 & 82.4\end{array}$

$0.6 \quad 15.5$

\section{Ni rich ores}

Hondekloof

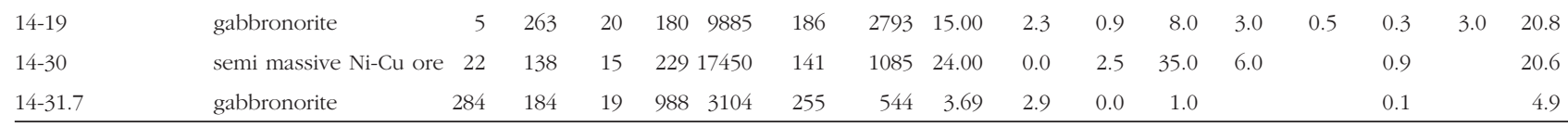


bodies comprising, in order of decreasing abundance, quartz-bearing anorthosite, various types of diorite and norite, and orthopyroxenite. Rocks of more alkaline affinity, such as glimmerite and syenite (often refererred as shonkinite in the literature) are less abundant (Conradie and Schoch 1986). The mineralisation in the Springbok area consists essentially of copper sulphides. Although mining has now come to an end, the sulphide mineralization produced and in reserve between 1939 and 1986 amounted to 94 million tons averaging $1.75 \% \mathrm{Cu}$ (Lombard et al., 1986). The mineralization is mainly hosted by the more mafic members of the suite, namely orthopyroxenite, norite, and, to a lesser extent, biotitebearing norite and diorite. Most economic bodies are 60 to $100 \mathrm{~m}$ wide and taper out at depth (Lombaard et al., 1986). Within the pipes, the more leucocratic phases (anorthosite-biotite diorite) are generally concentrated at higher levels and are interpreted to have intruded first, whereas the orthopyroxenites are more commonly located in the deeper levels and are interpreted to have intruded last (McIver et al., 1983; Van Zwieten et al., 1996; Clifford et al., 1995, and references therein). The richest ore tends to occur in the lower portions of the orthopyroxenites, such as at Carolusberg and Nigramoep mines (Potgieter 1996). The intrusions are generally associated with so-called "steep structures". These are narrow, " $\mathrm{D}_{4}$ " deformation zones along which the regional sub-horizontal planar fabric established during the "D2" regional deformation has been upturned into an antiformal cusp-like shape (Watkeys 1996; Kisters et al., 1996), possibly formed in a transpressional/dilatational regime (Lombaard and Schreuder 1978, Watkeys 1996). In addition, occasional copper-bearing, high-Th-U glimmerite intrusions with Koperberg Suite affinities were observed well to the north of the Springbok copper district, in the Steinkopf area (Andreoli et al., 2006).

Other mafic rocks relevant to our study that occurr in the Springbok area include hornblende-twopyroxene \pm biotite granulites of the Oorkraal Suite (formerly known as the Nuwefontein Suite: Hamman et al., 1996; C DeBeers, personal communication 2000) which are foliated and deformed by a "pre- $\mathrm{D}_{3}$ " tectonic event. They occur as raft-like inclusions/sills in the $\sim 1200 \mathrm{Ma}$ Nababeep orthogneiss and yield an emplacement age of $1168 \pm 9$ Ma by U-Pb SHRIMP on zircons (Lombaard et al., 1996; Robb et al., 1999; K. Beukes, personal communication 1994). These mafic granulites are compositionally distinct from the more rare, hornblende-free gabbroic rocks referred to as jotunite (Clifford et al., 2004; Duchesne et al., 2007). The latter were dated at $1035 \pm 13 \mathrm{Ma}$ and were proposed to represent a parental "chilled" melt from which the rocks and ores of the coeval (see above) Koperberg Suite were derived by fractionation.

The geology of the Hondekloof deposits near Kliprand (Figure 1) was investigated by Taylor (1990), Andreoli and Moore (1991), and Hamman et al. (1996) from whom the following description has been taken. The Kliprand area falls within the spinel+quartz upper granulite facies domain (D, Figure 1; Waters 1991) and thus represents a deeper crustal level than the Springbok area. In this area there are large bodies of megacrystic charnockite and charnockitic orthogneiss, mafic twopyroxene granulites of the Oorkraal Suite (Table 1; cf. De Beer, 2000) and an easterly-trending belt of predominantly supracrustal rocks (Albat 1984; Moore 1989). The latter represents a zone of monoclinal steepening and local shearing. It consists of calcsilicate rocks, metapelites, biotite-garnet gneisses, quartzite and ferruginous rocks belonging to the de Beer Kamiesberg Subgroup of the Bushmanland Group (de Beer 2000). Scattered within the belt are lenticular to irregularlyshaped bodies/sheets of melanocratic to mesocratic biotite granulites/gneisses of the pre-to early syntectonic Oorkraal Suite (Table 1; cf. de Beer, 2000) and less deformed lenses/sheets/outcrops of mafic biotitehornblende-metagabbro, orthopyroxenite, gabbronorite, leuconorite, anorthosite, diorite and glimmerite with the characteristics of the Koperberg Suite (Table 2).

The nickel deposits occur as small lenticular gossans along the basal contacts between poorly-banded, granulitic gabbronorite and banded migmatitic biotitegarnet paragneiss. Many lenses occupy fold hinges and are strung within a $1200 \mathrm{~m}$ wide, $3.5 \mathrm{~km}$ long belt of steepened foliation. Hamman et al. (1996) reported gradational contact relationships between sulphide-rich and sulphide-poor mafic lithologies (Table 2) and interpreted these bodies to be syn- to late tectonic and co-genetic with the Koperberg Suite. In their model, the sulphides were mobilized and concentrated during tectonism (accompanied by pervasive shearing) to sites of reduced strain represented by the fold hinges. This resulted in thick sulphide-enriched crests with long and thin attenuated, often disrupted fold limbs. The lateral and vertical discontinuity of the sulphide bodies, and possibly also that of the gabbronorite host, is attributed to this deformational event (J. Hattingh, personal communication 2008). Shallow drilling in the early 1980s defined in situ ore resources totalling $2 \mathrm{Mt}$ at $0.88 \% \mathrm{Ni}$ and $0.2 \% \mathrm{Cu}$. More recently, however, renewed drilling has significantly extended the reserves (J. Hattingh, personal communication)

\section{Mineralogy and Petrology}

Most of the basic bodies in the Springbok/O'okiep area are relatively unaltered and are essentially composed of plagioclase $\left(\mathrm{An}_{32-74}\right)$ and orthopyroxene $\left(\mathrm{En}_{58-68}\right)$. In most bodies, orthopyroxene is significantly more primitive than plagioclase (van Zwieten et al., 1996). Phlogopite, quartz, magnetite, spinel (hercynite) and sulphides are additional common minerals, whereas clinopyroxene is rare (McIver et al., 1983; Conradie and Schoch 1986; Brandriss and Cawthorn 1996). Apatite and zircon are abundant trace phases and may be locally highly enriched (e.g. at Ezelsfontein). Allanite or monazite are 
Table 2. Koperberg Suite meta-gabbronorites.

\begin{tabular}{|c|c|c|c|c|c|c|c|c|c|c|}
\hline Column & 1 & 2 & 3 & 4 & 5 & 6 & 7 & 8 & 9 & 10 \\
\hline \multirow[b]{2}{*}{$\mathbf{N}=$} & \multicolumn{2}{|r|}{ ore } & \multicolumn{2}{|c|}{ low grade ore } & \multicolumn{4}{|c|}{ Non mineralized } & \multicolumn{2}{|c|}{ jotunite } \\
\hline & 1 & 1 & 1 & 1 & 1 & 1 & 5 & 1 & 1 & 2 \\
\hline$\widehat{\mathrm{SiO}_{2}}$ & 20.41 & 25.08 & 36.05 & 39.68 & 43.12 & 49.88 & 53.58 & 55.43 & 56.01 & 52.86 \\
\hline $\mathrm{TiO}_{2}$ & 1.35 & 1.6 & 1.3 & 1.5 & 5.24 & 2.38 & 2.97 & 3.26 & 1.14 & 2.40 \\
\hline $\mathrm{Al}_{2} \mathrm{O}_{3}$ & 7.46 & 6.3 & 9.11 & 6.57 & 14.57 & 15.5 & 15.72 & 14.29 & 13.76 & 13.85 \\
\hline $\mathrm{Fe}_{2} \mathrm{O}_{3}$ tot & 53.31 & 43.89 & 35.96 & 32.7 & 12.62 & 11.17 & 11.2 & 9.86 & 7.9 & 13.98 \\
\hline $\mathrm{MnO}$ & 0.05 & 0.13 & 0.08 & 0.26 & 0.09 & 0.11 & 0.15 & 0.12 & 0.08 & 0.20 \\
\hline $\mathrm{MgO}$ & 4.87 & 4.98 & 3.91 & 10.83 & 7.93 & 7.96 & 5.06 & 2.47 & 5.87 & 4.12 \\
\hline $\mathrm{CaO}$ & 1.75 & 3.02 & 3.51 & 3.24 & 5.26 & 5.59 & 7.02 & 6.66 & 5.31 & 8.24 \\
\hline $\mathrm{Na}_{2} \mathrm{O}$ & 0.71 & 0.02 & 0.66 & 0.54 & 1.38 & 1.93 & 2.28 & 3.23 & 1.8 & 2.70 \\
\hline $\mathrm{K} 2 \mathrm{O}$ & 1.6 & 0.51 & 1.04 & 0.95 & 4.59 & 1.62 & 0.95 & 0.47 & 2.77 & 1.49 \\
\hline $\mathrm{P}_{2} \mathrm{O}_{5}$ & 0.16 & 0.4 & 0.38 & 0.32 & 1.98 & 0.8 & 0.72 & 1.17 & 1.58 & 0.73 \\
\hline LOI & 9.02 & 12.85 & 6.91 & 2.84 & 1.98 & 2.1 & 0.52 & 3.44 & 2.1 & \\
\hline Total & 100.69 & 98.78 & 98.91 & 99.43 & 97.82 & 99.04 & 100.17 & 101.32 & 98.23 & 100.57 \\
\hline $\mathrm{Rb}$ & 159 & 186 & 63 & 37 & 392 & 135 & 56 & & 173 & 47 \\
\hline $\mathrm{Sr}$ & 124 & 375 & & & 201 & 319 & 502 & 548 & 2211 & 197 \\
\hline $\mathrm{Ba}$ & 285 & 336 & 465 & 375 & 730 & 828 & 875 & 230 & 5604 & 840 \\
\hline $\mathrm{Y}$ & 13 & 21 & & & 61 & 34 & 42 & 61 & 38 & 71 \\
\hline $\mathrm{Zr}$ & 58 & 75 & & 205 & 226 & 247 & 305 & 1814 & 717 & 418 \\
\hline $\mathrm{Nb}$ & 10 & 11 & & & 54 & 16 & 13 & 21 & 13 & 22 \\
\hline $\mathrm{La}$ & 85.1 & 21.8 & 21.2 & 20.4 & 57 & 48.85 & & 59 & 279 & 57 \\
\hline $\mathrm{Ce}$ & & 11.3 & 47.0 & 42.3 & 153 & 102.3 & & 136 & 520 & 124 \\
\hline $\mathrm{Nd}$ & & & & & 109 & & & 85 & 257 & 65 \\
\hline $\mathrm{Sm}$ & 16.2 & 4.8 & 4.9 & 4.4 & & 0.5 & & & & 13 \\
\hline $\mathrm{Eu}$ & & & 1.4 & 1.1 & & 1.8 & & & & 3 \\
\hline $\mathrm{Tb}$ & 0.8 & 0.6 & 0.7 & 0.7 & & 2.0 & & & & 3 \\
\hline $\mathrm{Yb}$ & 1.5 & 1.9 & & & & 3.2 & & & & 6 \\
\hline Th & 38.4 & 1.9 & 1.9 & 3.2 & 4 & 7.2 & & 5 & 75 & 1 \\
\hline $\mathrm{U}$ & 2.3 & 0.8 & 0.7 & 0.8 & 5 & 1.5 & & 6 & 15 & 1 \\
\hline $\mathrm{Co}$ & 1016 & 947 & & 320 & 45 & 34 & 26 & & & 321 \\
\hline $\mathrm{Ni}$ & 16966 & 17195 & 12432 & 6520 & 101 & 92 & 128 & 66 & 330 & 41 \\
\hline $\mathrm{Cu}$ & 582 & 2720 & & & 42 & 18 & 42 & 147 & 170 & 165 \\
\hline $\mathrm{V}$ & 104 & 49 & 149 & & 398 & 179 & 196 & 172 & 110 & 38 \\
\hline $\mathrm{Cr}$ & 487 & 140 & 318 & 676 & 133 & 609 & 173 & 17 & 156 & 72 \\
\hline $\mathrm{Zn}$ & 158 & 267 & & & 242 & 257 & 142 & 172 & 118 & 143 \\
\hline Col. 1 & & F $14-46$ & & & & & & & & \\
\hline Col. 2 & & F $14-23.6$ & & & & & & & & \\
\hline Col. 3 & & F 14 B & & & & & & & & \\
\hline Col. 4 & & F 14 C & & & & & & & & \\
\hline Col. 5 & & F $15-11$ & & & & & & & & \\
\hline Col. 6 & & F $15-23.6$ & & & & & & & & \\
\hline Col. 7 & & M 543 & NAM 900 & NAM 902 & ET 1 & & ET 11 & & & \\
\hline Col. 8 & & F 26-15 & & & & & & & & \\
\hline Col. 9 & & F 26-19 & & & & & & & & \\
\hline Col. 10 & & nples 35, 3 & (Duchesne et al. & 07) & & & & & & \\
\hline
\end{tabular}

also occasionally present in cupriferous biotite norite ore (Andreoli et al., 2006). The rocks have highly equilibrated textures, indicative of metamorphic recrystallisation at granulite facies conditions. Together with the age data summarized above this suggests intrusion of the Koperberg Suite shortly before or during peak metamorphic conditions (Robb et al., 1999; Clifford et al., 2004; Andreoli et al., 2006), unlike many other magmatic Ni-Cu deposits on Earth that formed in extensional, rift related settings (Barnes and Lightfoot, 2006).

Opaque minerals in the mineralized rocks comprise approximately 50\% magnetite (Cawthorn and Meyer 1993), unusually high for magmatic ores where magnetite generally constitutes between 5 and 10\% of the total opaque component (Naldrett 1989). In most bodies, the sulphide assemblage is dominated by bornite and chalcopyrite (Carolusberg-type ore, e.g. 
at Carolusberg, Rietberg, and Homeep), but in some deposits, such as East O'okiep, Narrap, and Ezelsfontein, pyrrhotite is abundant, minor pentlandite is present, whereas bornite is absent (Narrap-type ore). At several deposits, including Hoits, Nigramoep, Jan Coetzee, and Spektakel, younger (600 to $500 \mathrm{Ma}$ ) metamorphic and meteoric fluids have remobilized $\mathrm{Cu}$ to form sulphides such as chalcocite and covellite, as well as abundant sericite, epidote and chlorite (Hoits-type ore, Clifford et al., 2012). In all deposits, the sulphides are mainly disseminated, but may locally occur as massive pods and as veinlets and veins, reflecting remobilization. All rock types in the O'okiep district have a strong crustal signature $\left({ }_{\varepsilon} \mathrm{Nd}\right.$ around $-9 ; \mathrm{Sr}_{\mathrm{i}} 0.7061$ to 0.7272 , $\delta^{34} \mathrm{~S}-4$ to +4 , and high $\mu$ values; von Gehlen et al., 1990; Boer et al., 1994; Clifford et al., 1995; Van Zwieten et al., 1996; Brandriss and Cawthorn 1996). The frequent, at times even extraordinary enrichment of members of the Koperberg Suite in U, Th and the REE (hosted by accessory minerals such as zircon, monazite, allanite, etc.) well above world averages for mafic rocks and granulites, is also notable (Andreoli et al., 1994; 2006, and references therein).

At Hondekloof, the host rock is mainly a mediumgrained gabbronorite consisting, on average, of plagioclase (64\%), orthopyroxene (14\%), clinopyroxene (11\%), and phlogopitic mica (7\%) with minor quartz and accessory apatite and opaque minerals. Where clinopyroxene is absent the rocks hold less phlogopite and have a noritic composition; and where hypersthene is less prominent, dioritic (sulphide-bearing) compositions predominate. The plagioclase has $\mathrm{An}_{45-55}$ and orthopyroxene has $\mathrm{En}_{53-62}$. Chadacrysts of plagioclase, clinopyroxene, phlogopitic mica, apatite and opaque minerals occur in some of the hypersthene grains. The clinopyroxene is colourless to pale green and has a salite composition. It poikiloblastically encloses most of the other minerals suggesting simultaneous growth during recrystallization (J. Hattingh, personal communication). The concentration of phlogopitic mica is extremely variable, from an average of 7 up to 90 modal per cent in the glimmeritic rocks. Surprisingly, monazite and fluorspar were found as accessories in low grade dioritic - glimmeritic ore rocks. In contrast to the Cu-rich nature of the O'okiep sulphide assemblages, the Hondekloof sulphides consist largely of pyrrhotite, containing pentlandite flames and blebby chalcopyrite. The $\delta^{34} \mathrm{~S}$ of the sulphides is -2.2 to -3.6, overlapping with the sulphur isotopic signature of sulphides at O'okiep.

The available data suggest that the felsic members of the Koperberg Suite were derived from protoliths that were isotopically heterogeneous at the regional scale. The intrusions in the O'okiep district have $\varepsilon N d$ significantly lower (range: -8 to $-10 ; \mathrm{T}_{\mathrm{CHUR}} \sim 1800 \mathrm{Ma}$ ) than the monazite-bearing intrusive at Steenkampskraal (ca. -1.8 to $-1.3 ; \mathrm{T}_{\mathrm{CHUR}} \sim 1050$ to $1160 \mathrm{Ma}$; Andreoli et al., 2006)

\section{New results}

In the present study we determined the platinum-group elements (PGE), Cu, Ni, S, and some selected other elements in 28 samples from the O'okiep copper district and from Hondekloof. The data are presented in Table 1, together with data from ten samples from Carolusberg and East O'okiep presented previously (Maier, 2000). All analyses were carried out at the University of Quebec at Chicoutimi, Canada. The PGE and $\mathrm{Au}$ were determined by Ni-sulphide fire assay followed by instrumental neutron activation analysis (INAA), using the method described in Maier and Barnes (1999). Nickel and Cu were determined by Atomic Absorption (AA) spectroscopy, S by LECO titration, the remaining elements were determined by INAA using the method of Bédard and Barnes (2002). Copper, $\mathrm{Ni}$ and $\mathrm{S}$ contents in the samples from Carolusberg, East and West O'okiep, and Jubilee are given in Cawthorn and Meyer (1993).

Bulk PGE contents in the samples are highly variable, from below detection limit to about 1 ppm. The bulk of the PGE component consists of Pt and Pd. Iridium contents are generally below $2 \mathrm{ppb}$. The lowest PGE contents occur in the Ni-rich ores from Hondekloof and Ezelsfontein, and in some Cu-rich ores, notably from East O'okiep and West O'okiep. The most PGEenriched ores occur at Homeep, Carolusberg West, and Nigramoep. The PGE tenors of the sulphides are highly variable: at Carolusberg and Homeep the Pt+Pd contents in $100 \%$ sulphide reach approximately 1 to $4 \mathrm{ppm}$, but at most of the other localities the tenors are much lower, notably in the Ni rich ores from Ezelsfontein and Hondekloof.

Compared to most other magmatic sulphide ores, the Au contents are relatively high, exceeding PGE contents in most samples. The average Au content of all samples is $69 \mathrm{ppb}$, compared to $29 \mathrm{ppb} \mathrm{Pd}$ and $31 \mathrm{ppb} \mathrm{Pt}$. Similarly high $\mathrm{Au} / \mathrm{PGE}$ ratios were recorded at Caraiba, Brazil (Maier and Barnes, 1999) and in some of the Sudbury mines (e.g. Cu-rich sulphide stringers at Little Stobie; Hoffman et al., 1979).

The metals correlate with $\mathrm{S}$ in individual deposits, but the total sample population shows unsystematic scatter in binary metal/S plots (Figure 3). The least scatter is found in $\mathrm{Cu} / \mathrm{S}$ and $\mathrm{Ni} / \mathrm{S}$.

The mantle-normalised PGE patterns are strongly fractionated ( $\mathrm{Pd} / \mathrm{Ir}$ up to 100$)$ with negative Ir anomalies and a progressive increase in concentration from Ir to $\mathrm{Cu}$ (Figure 4). The lowest $\mathrm{Pd} / \mathrm{Ir}$ occurs in the Ni-rich ores, at Ezelsfontein (average 37) and Hondekloof (average 27). The $\mathrm{Pd} / \mathrm{Ir}$ ratios in the $\mathrm{Cu}$-rich ores are higher than those of most other sulphides hosted by differentiated gabbroic rocks. The closest analogies are again the Caraiba norites-pyroxenites in Brazil (Pd/Ir 72; Maier and Barnes 1996, 1999) and Cu-rich ores at Sudbury (Naldrett et al., 1982).

Some new lithophile whole rock-data from the Hondekloof gabbronorites in the Kliprand area are given in Table 2. The bulk major-, minor and trace element 

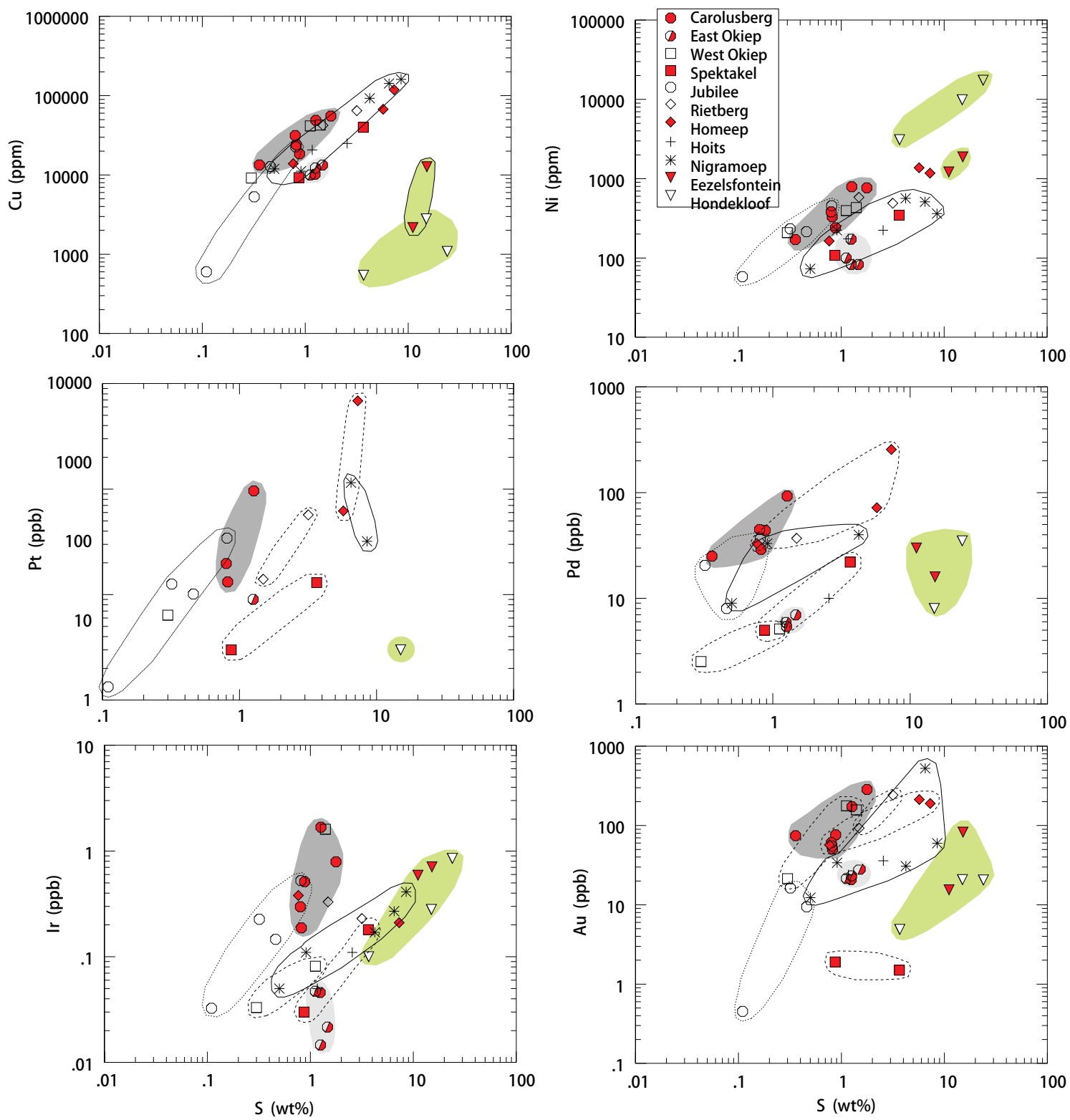

Figure 3. Binary variation diagrams vs $S$ of (i) Cu, (ii) Ni, (iii) Pt, (iv) Pd, (v) Ir, and (vi) Au. Note that most of the data correlate positively with $S$, but individual deposits define distinct fields.

composition of the rocks bears some similarities to the Koperberg Suite Table 2), but also to the maficintermediate granulites and gneisses of the Oorkraal Suite (Table 3) and the two-pyroxene granulite (jotunite) of the Springbok area (cf. Table 2; Hamman et al., 1996; Duchesne et al., 2007). The rocks have distinct crustal signatures, with strong, but variable relative enrichment in LIL and HFS elements, and negative $\mathrm{Nb}-\mathrm{Ta}, \mathrm{Sr}$, and Ce anomalies (Figure 2). In both the Hondekloof gabbronorites and the Koperberg Suite in the Springbok area the mineralised samples tend to contain lower concentrations of incompatible trace elements than the unmineralised samples. This trend appears nevertheless reversed in the case of the monazite-chalcopyrite ore at Steenkampskraal (Andreoli et al., 1994), certain monazite/allanite-Cu sulphides ores in the O'okiep District (Andreoli et al., 2006) and of the monazite-fluorspar-mica-sulphide bearing diorite (low grade ore) at Hondekloof (cf. Column 4, Table 2). 


\section{Discussion}

\section{Unbundling the nomenclature knot.}

Even a cursory appraisal of the literature on the O'okiep copper district reveals that the origin of these mineral deposits remains highly controversial. Because most publications focused on the Springbok area, we contend that at least some of the issues may be cleared by considering the wider geographic perspective of centralsouthern Namaqualand. For instance, our observations, both at Okiep and at Vaalputs and Kliprand, severely constrain Duchesne et al.'s (2007) model which derives the Koperberg Suite via the fractionation of jotunite, because field exposures of such rocks appear to be much rarer than suggested by these authors. Duchesne et al. (op. cit.) equated an occurrence of $1035 \pm 15 \mathrm{Ma}$ (Clifford et al., 2004) unmetamorphosed jotunite to the extensive sheets of Oorkraal Suite mafic (two-pyroxene, hornblende granulites found in the same area (cf. Lombaard et al., 1986). However, these rocks [that is the two-pyroxene granulites in the Springbok area] are older, yield a $1168 \pm 9$ Ma emplacement age, and a 1063 $\pm 16 \mathrm{Ma}$ metamorphic age (Robb et al., 1999) and have a sub-alkaline, high-Mg tholeiitic basalt composition (cf. Table 1; Reith and Meisel, 2001). A comparable confusion was seemingly repeated in the Kliprand area, where Hamman et al. (1996) attributed to the Nuwefontein Suite both the regionally extensive sheets of two-pyroxene granulites and a string of less
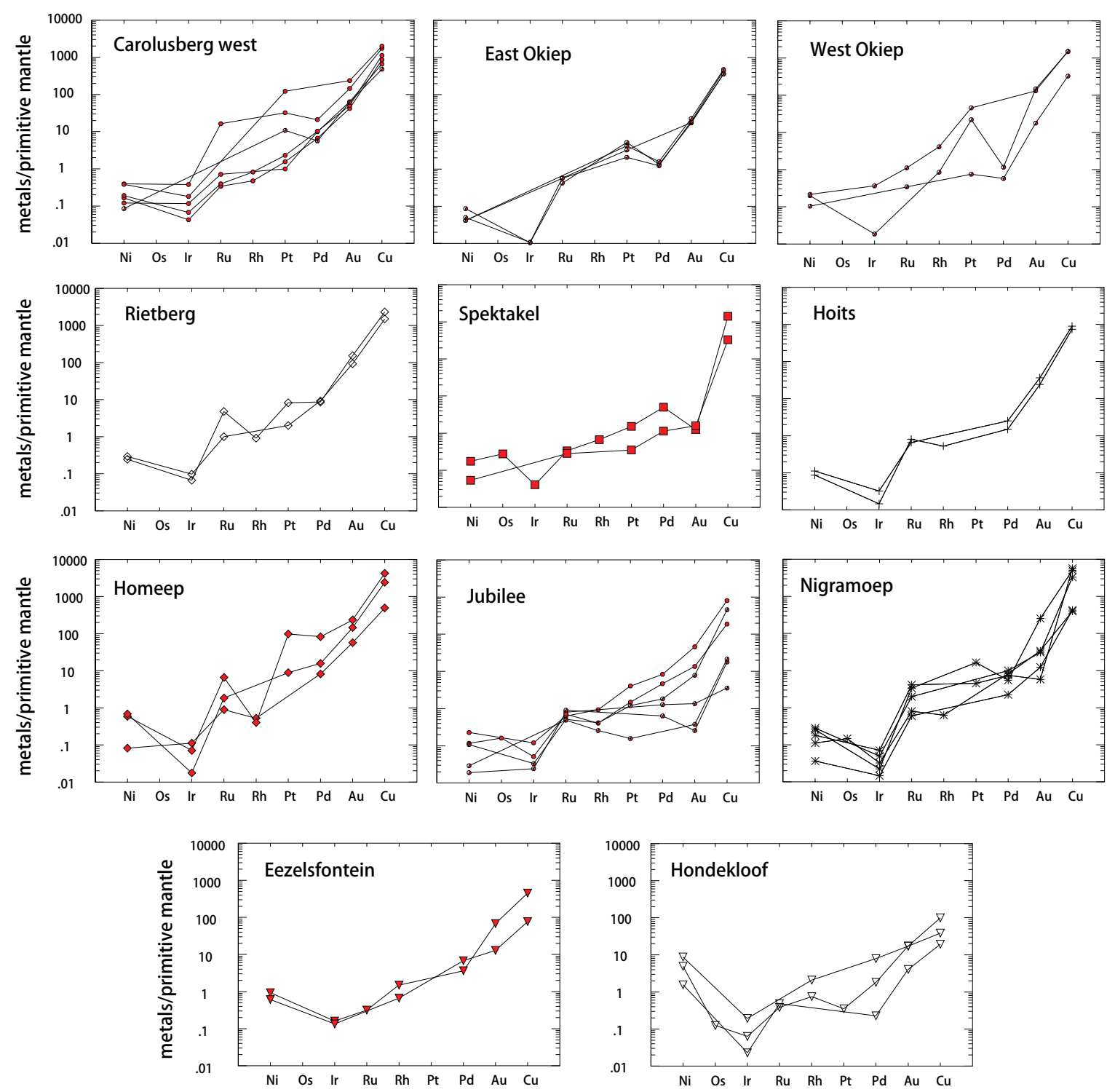

Figure 4. Mantle-normalised metal plots for the O'okiep and Hondekloof ores. Primitive mantle normalization values are from Barnes and Maier (1999). 
Table 3. Whole-rock compositions of selected metagabbro and mafic to intermediate granulites of the Oorkraal suite

deformed Koperberg Suite bodies structurally confined to an easterly-trending monoclinal, sheared structure (Taylor, 1991; Andreoli and Moore, 1991). Our new data, complemented by mapping by Taylor (1991), the Council for Geoscience (C. de Beer, personal communication, 2008) and, most recently, by prospecting activities for nickel (Johann Hattingh, personal communication 2008) correlate the barren twopyroxene granulites of the Nuwefontein Suite to the Oorkraal Suite, and the nickeliferous gabbronorites and related rocks (anorthosite, diorite, glimmerite) to the younger Koperberg Suite. On this basis we propose to discontinue the use of the term "Nuwefontein Suite".

\section{Magmatic lineage of the mineralised rocks.}

Previous workers suggested that the Koperberg sulphides crystallized from sulphide melt that segregated from an alkaline basaltic or anorthositic magma, in response to contamination with peraluminous granitic country rocks (McIver et al., 1983; Schoch and Conradie 1990; Boer et al., 1994; Van Zwieten et al., 1996). Probably the main argument is the unusual combination of differentiated silicate phases, enrichment in incompatible elements (including LILE and HFSE), and crustal $\mathrm{Nd}$ isotope signatures on the one hand, with elevated $\mathrm{Cr}$ and $\mathrm{Ni}$ contents on the other hand.

An anorthositic - jotunitic lineage might be consistent with the rare dykes of jotunite in the O'okiep Copper district (Clifford et al., 2004; Duchesne et al., 2007) and the observed enrichment in magnetite, apatite, relatively sodic plagioclase, and ferrous orthopyroxene in the Koperberg Suite. The hyper-enrichment of certain sulphide-bearing members of the same suite in Large Ion Lithophile (LIL) and High Field Strength (HFS) elements, as exemplified by the $\sim 5 \times 10^{5}$ tonnes of monazitechalcopyrite concentrate once mined from the 
Steenkampskraal thorium mine (Andreoli et al., 1994; 2006; Schoch and Conradie, 1990) would have to be explained by a highly trace element-enriched contaminant, such as a small-degree melt of the country rocks, or a sub-continental lithospheric mantle (SCLM) component (see below).

Evidence for an alkaline signature is ambiguous. This is because the compositional characteristics of alkaline magmas resemble those of crustally contaminated magmas in many regards (i.e. fractionated incompatible element patterns, volatile enrichment, negative ${ }_{\varepsilon} \mathrm{Nd}$, high initial $\mathrm{Sr}$ isotope ratios, etc.) which in turn reflects the derivation of many alkaline magmas from refractory SCLM refertilised by crustally-derived fluids and melts (Francis and Ludden, 1995). Partial melts of the SCLM can be alkaline if derived by small degree of melting (e.g. kimberlites and many alkali basalts) or tholeiitic if derived by larger degrees of melting (e.g. Bushveld magmas; Harmer and Sharpe, 1985; Richardson and Shirey, 2009). Therefore, all that can be said at present on the petrogenesis of the parental magmas to the O'okiep and Hondekloof deposits is that they are derived from a relatively differentiated mafic magma of basaltic lineage, containing a large HFSE/lithophile element component, either derived from metasomatised mantle and/or via contamination of asthenospheric mantle melt by crust (cf Andreoli et al., 2006).

Stumpfl et al. (1976) also envisaged a broadly basaltic lineage for the deposits, but in most other aspects their model is radically different from that of other authors in that they suggested anatexis of a lower crustal mafic protolith and ascent and intrusion of felsic partial melt entraining restitic material. This model would be consistent with the high-grade metamorphic setting of both the Curaca Valley and O'okiep ores. In the case of a gabbroic to dioritic protolith, the restitic phases may consist mainly of pyroxenes (Osborn, 1978). Crustal anatexis of a dioritic protolith would probably yield dry melts with silica activities equal to unity, and such melts would not be able to dissolve much $\mathrm{P}_{2} \mathrm{O}_{5}, \mathrm{Zr}$, or $\mathrm{Fe}^{3+}$, resulting in refractory behaviour of magnetite, apatite, and zircon. Segregation of these residual phases during ascent and intrusion may yield the unusual ultramafic assemblages predominantly observed in the lower portions of pipes in the O'okiep district, namely orthopyroxene-magnetite (+apatite) (Maier, 2000).

\section{Models of ore formation}

Past workers have modelled the O'okiep ores by various processes, none of which is considered entirely

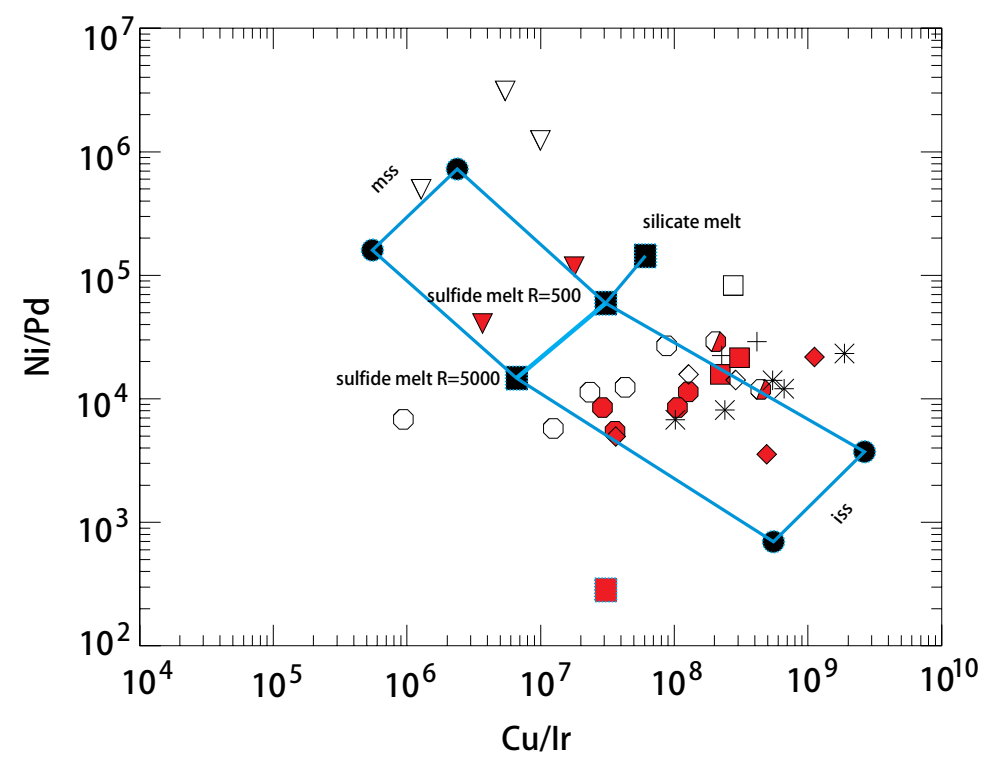

Figure 5. Plot of Ni/Pd vs Cu/Ir. O'okiep and Hondekloof ores can theoretically be modeled by a multistage process, involving sulphide segregation from differentiated magma of picritic lineage (150 ppm Cu, 40 ppm Ni, 0.35 ppb Pd, 0.0025 ppb Ir), followed by sulphide fractionation and separation of mss ( $F=0.9, D$ of 0.22 for Cu, 2 for Ni, 0.15 for Pd and 3 for Ir) and iss (F=0.2) components. However, ores with Cu/Ni ratios as high as observed at O'okiep have not yet been observed elsewhere. See text for discussion, and Figure 1 for symbols. 


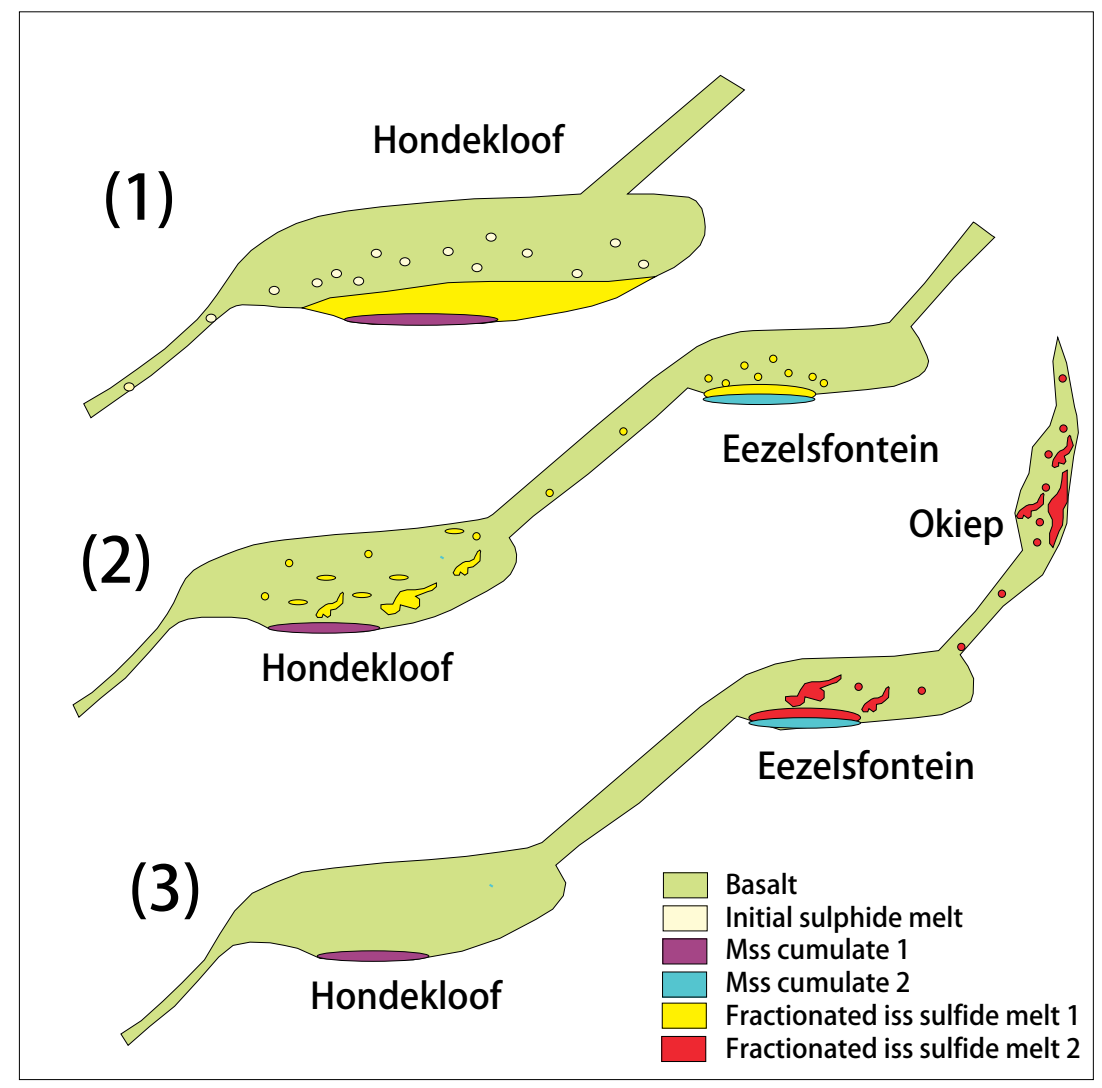

Figure 6. Schematic model of ore formation at O'okiep and Hondekloof. Basaltic, relatively Cu-rich and PGE-poor magma was generated through low-degree partial melting in the sub-continental lithospheric mantle. The magma differentiated during ascent through the crust. Sulphide saturation was triggered by contamination. Continued ascent in dynamic magma conduits led to extensive fractionation of the sulphide liquid. (1) Relatively Ni-rich cumulate ores formed by mss fractionation in deep intrusions such as Hondekloof. (2) Residual sulphide liquid was entrained and re-deposited at Eezelsfontein. Renewed mss fractionation produced relatively Ni-rich cumulates and Cu-rich residual liquid. (3) Continued magma flux led to entrainment of highly fractionated sulphide melt to shallowest intrusions at O'okiep. See text for explanatio

satisfactory to explain all the characteristics of the deposits:

i. Based on the unusual sulphide assemblage in the Koperberg Suite, particularly the abundance of bornite, Cawthorn and Meyer (1993), Boer et al. (1994), and Van Zwieten et al. (1996) proposed that the ores formed by metamorphic oxidation and desulphidization of a primary magmatic sulphide assemblage derived from mantle basalt, dominated by pyrrhotite and chalcopyrite, to an assemblage consisting of chalcopyrite, bornite, and Ti-free magnetite:

$5 \mathrm{CuFeS}_{2}+5 \mathrm{FeS}+6 \mathrm{H}_{2} \mathrm{O}+\left[8 \mathrm{O}_{2}\right]=\mathrm{Cu}_{5} \mathrm{FeS}_{4}+3 \mathrm{Fe}_{3} \mathrm{O}_{4}+6 \mathrm{H}_{2} \mathrm{~S}+5 \mathrm{SO}_{2}$ cp po bn $\mathrm{mag}$
The model would provide an explanation for the abundance of bornite and magnetite in the most Curich ores. Similarly Cu-rich ores in other metamorphic terrains (e.g. at Caraiba) also are characterised by abundant bornite and magnetite (Maier and Barnes, 1999). However, the model provides no explanation for the extremely high $\mathrm{Cu} / \mathrm{Ni}$ ratios of the O'okiep ores, and the low $\mathrm{Cu} / \mathrm{Ni}$ at Hondekloof. Therefore, an additional or alternative mechanism is required.

ii. The high $\mathrm{Cu} / \mathrm{Ni}$ ratios and the abundance of mica in the mineralized rocks of the Koperberg Suite could suggest in situ hydrothermal or metamorphic remobilization or introduction of $\mathrm{Cu}$ to the mafic rocks via an aqueous fluid phase, but this model 
is considered unlikely as the mineralization is exclusively associated with the mafic-ultramafic rocks within a high- $\mathrm{T}$, low- $\mathrm{a}_{\mathrm{H} 2 \mathrm{O}}$ granulite facies environment (Waters, 1986; Clifford et al., 1994; Andreoli et al., 2006).

iii. The ascending basic magma may have assimilated $\mathrm{Cu}$ from deep-seated Cu-bearing country rocks, for example porphyry copper deposits within the Eburnian-aged basement rocks to the north of the O'okiep district (Minnitt, 1986). Copper porphyries can contain significant $\mathrm{Au}$ and, in some cases, also PGE (Economou-Eliopoulos, 2005). The O'okiep and Hondekloof rocks have distinct crustal isotope signatures consistent with significant crustal contamination (van Zwieten et al., 1996; Brandriss and Cawthorn, 1996). However, the model is unsatisfactory as presently it cannot be directly constrained.

iv. Based on the common high-grade metamorphic setting of the Caraiba and O'okiep ores, Maier and Barnes (1999) and Maier (2000) suggested that the $\mathrm{Cu}$-rich sulphides formed by partial melting of lower crustal rocks containing $\mathrm{Cu}$-rich proto sulphides (see also Stumpfl et al., 1976; Clifford et al., 1995; 2004; 2012; Duchesne et al., 2007), followed by entrainment and fractionation of sulphide melt in slurries of anatectic melt and restite. The model is consistent with the crustal signature of the silicate and sulphide minerals, the disequilibrium compositions of, e.g., plagioclase and orthopyroxene, and potentially the low PGE contents and high Au/PGE ratios of the sulphides. However, the model is more difficult to apply to the relatively Ni-rich Hondekloof ores as any sulphide melts that formed during partial melting of crust might be expected to equilibrate with residual mafic components, resulting in compatible behaviour of Ni. Hondekloof would thus have to represent a relatively more restitic component, inconsistent with the composition of the silicates.

v. The Cu- and Ni-rich ores could have formed through extreme fractionation of a magmatic sulphide liquid. The main challenge for this model is to explain the relatively Ni-rich Hondekloof ores. The mineral chemistry of the Hondekloof biotite gabbros and norites is as evolved as that of the O'okiep intrusions, consistent with a differentiated basaltic parent melt in both districts, but $\mathrm{Ni}$ contents and $\mathrm{Ni} / \mathrm{Cu}$ ratios of the Hondekloof sulphides are much higher than at O'okiep. Compositional ranges of potential sulphide liquids can be evaluated by simulating fractional crystallization of basaltic-picrite magma using thermodynamic modelling software such as PELE. Assuming a picritic starting composition (e.g., olivine-phyric basalt from Cape Smith; Barnes and Picard, 1995) and lower- to mid-crustal pressure, residual basalt crystallizes pyroxene and plagioclase of the composition recorded at Hondekloof after approximately 50\% fractional crystallization (in detail, the modelling is dependent on $\mathrm{H}_{2} \mathrm{O}$ content and $f \mathrm{O}_{2}$, but generalized trends are sufficient for the present purpose). At this stage of solidification, the magma would have 3 to $4 \% \mathrm{MgO}$, $45 \mathrm{ppm} \mathrm{Ni}$, and several hundred ppm $\mathrm{Cu}$ as long as the magma was sufficiently oxidized so that largescale sulphide saturation was not achieved. Assuming R factors between 500 and 5000, the sulphide melt has about 5 to $7.5 \% \mathrm{Cu}, 1$ to $1.3 \% \mathrm{Ni}$, and $\mathrm{Cu} / \mathrm{Ni}$ ratios of at least 5 , an order of magnitude higher than Hondekloof sulphides. To produce ores with 1.5 to $2 \% \mathrm{Ni}$ and $\mathrm{Cu} / \mathrm{Ni} 0.2$ to 0.5 , as at Hondekloof, the crystallizing mss needs to fractionate from the residual sulphide melt after as little as $10 \%$ crystallization. The Cu-rich O'okiep ores may theoretically be produced by fractionation of iss after advanced crystallization of the sulphide liquid $(\mathrm{F}=0.2)$ (Figure 5). A concern with this model is that $\mathrm{Cu} / \mathrm{Ni}$ ratios as high as at O'okiep have not yet been recorded in magmatic ores elsewhere. Another problem is that the metal-rich nature of the O'okiep sulphides requires the magma to remain undersaturated in sulphide melt during advanced differentiation. This is difficult to reconcile with the low PGE contents of the ores. One could argue that the magma merely attained temporary sulphide saturation. This resulted in segregation of only a small amount of sulphide melt that failed to deplete $\mathrm{Cu}$ in the magma, whereas the highly chalcophile PGE were effectively stripped from the magma. However, due to the homogenous PGE depletion of all deposits in the district, this model seems implausible.

In view of the above considerations, we presently favour a composite model incorporating new ideas as well as elements of some of the above models, as discussed below.

\section{Genetic links to the IOCG group of deposits.}

The O'okiep deposits bear certain similarities to the Caraiba copper deposits of Brazil (Oliveira and Tarney, 1995; Maier and Barnes, 1996, 1999). In a global context, the O'okiep, Caraiba and Phalaborwa copper deposits may be rare magmatic end-members of the IOCG class of deposits (Andreoli et al., 2006, Groves and Vielreicher, 2001). A related deposit may be the occurrence at Otjisuzubin in the Damara belt of Namibia, where anomalous copper is associated with apatite in an alkaline complex comprising alkali pyroxenite, sövite, mafic pegmatoids and syenite (Gunthorpe and Burger, 1986). Another unique deposit, i.e. the Vergenoeg pipe of fayalite-magnetite-fluorite probably represents a Cu-poor variant sited in the centre of the Kaapvaal Craton (Goff et al. 2004). This array of unique deposits suggests that the SCLM under southern Africa was anomalously fertile and raises the possibility of magmatic-hydrothermal IOCG deposits in the southern African terranes. One such deposit, previously unrecognised as a variant of IOCG, may be the Messina copper deposit in high-grade metamorphic rocks of the 
Central Limpopo belt. At Messina, anomalously S-poor assemblages of chalcopyrite, bornite and hypogene chalcocite and native copper, associated with hematite, occur in large breccia pipes (Jacobsen, 1974). The deposit occurs close to known diamondiferous kimberlite pipes at River Ranch and Venetia, and Jacobsen and McCarthy $(1975,1976)$ have suggested a genetic association with deep alkaline intrusions. It is suspected that the potential for IOCG deposits in southern Africa may not have been realised because of the anomalous nature of the deposits discovered to date, including the O'okiep deposits discussed here.

In the context of the IOCG model, the O'okiep magmatism would have been triggered by crustal extension, for example in response to orogenic collapse caused by extreme radiogenic heating at mid- to lower crustal depths (Mouri et al., 2003; Andreoli et al., 2006). As a result of this event, small-degree partial melting of the SCLM produced magmas that are variably enriched in volatiles, $\mathrm{CO}_{2}$, LILE, HFS, $\mathrm{Au}, \mathrm{Cu}, \mathrm{P}$, but also $\mathrm{SiO}_{2}, \mathrm{Cr}$, $\mathrm{MgO}$ and other compatible elements. In contrast, PGE contents of the magma were low, analogous to many alkaline magmas elsewhere (Maier and Barnes, 2004). The magma ascended rapidly into the crust due to its high volatile content. In the oxygenated magmas S was stable as sulphate (Mungall et al., 2006) preventing early sulphide saturation and allowing $\mathrm{Cu}$ and $\mathrm{Au}$ to be concentrated in the magma until the advanced stages of differentiation (Campbell et al., 1998, and references therein). Sulphide saturation was eventually triggered by contamination and addition of external S, causing low ${ }_{\varepsilon} \mathrm{Nd}$ and $\delta^{34} \mathrm{~S}$ values. The sulphides underwent extensive fractionation during continued magma ascent in dynamic magma conduits, possibly favoured by oxidation (cf Wohlgemuth-Überwasser et al., 2012). This resulted in deposition of relatively Ni-rich ores in deep intrusions such as Hondekloof, and progressively more Cu-rich ores with decreasing depth of emplacement (Figure 6). Because PGE and Au are incompatible into mss, they are enriched in the most $\mathrm{Cu}$-rich deposits. The relatively high $\mathrm{Au} / \mathrm{PGE}$ ratios of the ores mirror those of the SCLM (Maier et al., 2012).

\section{Conclusions}

The genesis of the Namaqualand $\mathrm{Cu}-\mathrm{Ni}$ ores can be linked to other Cu-Au-P-LREE enriched systems, such as Caraiba and the IOCG group of deposits. Key components of the model include magma generation at craton margins, in response to melting of metasomatised SCLM in a back arc environment. The volatile-rich, oxidized magmas formed through relatively small degrees of partial melting, resulting in low PGE contents. The magmas ascend rapidly into the crust through trans-lithospheric structures, delaying sulphide saturation until relatively advanced stages of differentiation, thus causing pronounced enrichment in $\mathrm{Cu}$, and incompatible lithophile elements.

Sulphide-bearing silicate rocks at O'okiep and Hondekloof show remarkable similarity in terms of petrography and composition of silicate minerals, leaving little doubt that they are co-genetic. In contrast, the sulphide ores at the two localities are of a distinctly different composition. At O'okiep there occur mainly Cu-rich sulphide minerals, dominated by bornite and chalcopyrite, with $\mathrm{Cu} / \mathrm{Ni}$ ratios reaching $>100$. At Hondekloof there occur Ni-rich ores dominated by pyrrhotite with $\mathrm{Cu} / \mathrm{Ni}$ ratios between 0.1 and 0.5 . Ores of intermediate composition occur at Ezelsfontein. The range of compositions can be explained by fractionation of magmatic sulphide melt during magma ascent and emplacement in dynamic conduit systems. This is particularly clear at Hondekloof because these ores are too Ni-rich to represent unfractionated primary magmatic sulphides segregated from their relatively differentiated host rocks. The model has potential exploration implications as it suggests potential in Namaqualand for more Ni-rich ores of the Hondekloof type. The Ni-rich ores would be expected to occur at deeper crustal levels than the Cu-rich ores, consistent with the emplacement of the Kliprand intrusion in upper $\left(\mathrm{T} \sim 860^{\circ} \mathrm{C}\right)$ granulite facies rocks relative to the O'okiep ores in lower granulite ( T $\sim 750^{\circ} \mathrm{C}$ ) facies.

\section{Acknowledgements}

We thank Gold Fields of South Africa, the O'okiep Copper Company, and the Foundation for Research Development of South Africa for financial support. Leslie Terreblanche, Koos Beukes, and several other staff at Nababeep mine offices guided WD Maier during fieldwork and mine visits at Carolusberg and Nigramoep mines. Rodger Hart (iThemba Labs Gauteng) kindly provided neutron activation analyses. Reviews by E Ripley and S Prevec helped to improve the paper.

\section{References}

Andreoli, M.A.G. and Moore, J., 1991. Geology and mineralogy of the Hondekloof nickel prospect, Kliprand, Cape Province. Atomic Energy Corporation of South Africa Internal Report GEA-968, 32pp. (2 unbound maps).

Andreoli, M.A.G., Smith, C.B., Watkeys, M., Moore, J.M., Ashwal, L.D. and Hart, R.J., 1994. The geology of the Steenkampskraal monazite deposit, South Africa: implications for REE-Th-Cu mineralization in charnockitegranulite terranes. Economic Geology, 89, 994-1016.

Andreoli M.A.G., Hart R.J., Ashwal L.D. and Coetzee H., 2006. Correlations between $\mathrm{U}$, Th content and metamorphic grade in the western Namaqualand belt, South Africa, with implications for radioactive heating of the crust. Journal of Petrology, 47, 1095-1118.

Barnes, S.-J. and Maier, W.D., 1999. The fractionation of Ni, Cu and the noble metals in silicate and sulphide liquids. In: R.R. Keays, C.M. Lesher, P.C. Lightfoot, C.E.G. Farrow (Editors), Dynamic processes in magmatic ore deposits and their application to mineral exploration. Geological Association of Canada, Short Course Notes, 13, 69-106.

Barnes, S.-J. and Picard, C.P., 1995. The behaviour of platinum-group elements during partial melting, crystal fractionation, and sulphide segregation: an example from the Cape Smith Fold Belt, northern Quebec. Geochimica et Cosmochimica Acta, 57, 79-87.

Boer, R.H., Meyer, F.M. and Cawthorn, R.G., 1994. Stable isotopic evidence for crustal contamination and desulfidation of the cupriferous Koperberg Suite, Namaqualand, South Africa. Geochimica et Cosmochimica Acta, $58,2677-2687$ 
Brandriss, M.E. and Cawthorn, R.G., 1996 Formation of anorthosite and leucotonalite during magma hybridization in the Koperberg Suite of Namaqualand, South Africa. South African Journal of Geology, 99, 135-151 Campbell, I.H., Compston, D.M., Richards, J.P., Johnson, J.P. and Kent, A.J.R., 1998. Review of the application of isotopic studies to the genesis of $\mathrm{Cu}$ Au mineralisation at Olympic Dam and Au mineralisation at Porgera, the Tennant Creek district and Yilgarn Craton. Austrailian Journal of Earth Science, 45, 201-218.

Cawthorn, R.G. and Meyer, F.M., 1993. Petrochemistry of the O'okiep copper district basic intrusive bodies, northwestern Cape Province, South Africa. Economic Geology, 88, 590-605.

Clifford, T.N., Barton, E.S., Retief, E.A., Rex, D.C. and Fanning, C.M., 1995. A crustal progenitor for the intrusive anorthosite-charnockite kindred of the cupriferous Koperberg Suite, O'okiep District, Namaqualand, South Africa; New isotope data for the country rocks and intrusives. Journal of Petrology, 36, 231-258

Conradie, J.A. and Schoch, A.E., 1986. Petrographical characteristics of the Koperberg Suite, South Africa - an analogy to massif-type anorthosites? Precambrian Research, 31, 157-188.

Duchesne, J.-C., Vander Aurewa, J., Liegeois, J.-P., Barton, E.S. and Clifford, T.N., 2007. Geochemical constraints of the petrogenesis of the O'okiep Koperberg Suite and granitic plutons in Namaqualand, South Africa: a crustal source in Namaquan (Grenville) times. Precambrian Research, $153,116-142$

Economou-Eliopoulos, M., 2005. PGE potential of porphyry deposits. In: J.E. Mungall (Editor), Exploration for platinum-group elements, Mineralogical Association of Canada, Short Course Series V 35.

Fraser, K.J., Hawkesworth, C.J., Erlank, A.J., Mitchell, R.H. and Scott-Smith, B.H., 1985. Sr, $\mathrm{Nd}$ and $\mathrm{Pb}$ isotope and minor element geochemistry of lamproites and kimberlites. Earth and Planetary Science Letters, $76,57-70$.

Gibson, R.L., Robb, L.J., Kisters, A.F.M., and Cawthorn, R.G., 1996. Regional setting and geological evolution of the O'okiep Copper District, Namaqualand, South Africa. South African Journal of Geology, 99, 107-120.

Goff, B.H., Weinerg, R., Groves, D.I., Vielreicher, N.M. and Fourie, P.J., 2004. The giant Vergenoeg fluorite deposit in a magnetite-fluorite-fayalite-REE pipe: a hydrothermally altered carbonatite-related pegmatoid? Mineralogy and Petrology, 80, 173-199.

Groves, D.I. and Vielreicher, N.M., 2001. The Phalaborwa (Palabora) carbonatite-hosted magnetite copper sulphide deposit, South Africa: an end-member of the iron-oxide copper gold rare-earth element deposit group?. Mineralium Deposita, 36, 189-194.

Gunthorpe, R.J. and Burger, A.D., 1986. Geoogy and economic evolution of the Otjisazu alkaline igneous complex, central South West Africa/ Namibia, In: C.R. Anhaeusser S. Marke (Editors), Mineral Deposits of Southern Africa. Geological Society of South Africa, 2255-2260.

Hamman, J.N., Rozendaal, A. and Jordaan, W., 1996. Gabbro norite hosted $\mathrm{Ni}-\mathrm{Cu}-\mathrm{CO})$ sulphide mineralization in southern Namaqualand and its relationship to the cupriferous Koperberg Suite of the O'okiep Copper District, South Africa. South African Journal of Geology, 99, 153-167.

Hronsky, J.M.A. and Groves, D.I., 2009. Towards a Unified Model for Magmatic-Hydrothermal Gold Metallogeny with Implications for Orogenic Gold. Abstr., Proc 10th SGA meeting, Townsville, Australia.

Jacobsen, J.B.E., 1974. Structure of the copper ore bodies and country rocks at Artonvilla mine, South Africa. Transactions of the Institute for Mining and Metallurgy, 83, B60-B64.

Jacobsen, J.B.E. and McCarthy, T.S., 1976. Possible late Karoo carbonatite and basalt intrusions at Messina, Transvaal. Transactions of the Geological Society of South Africa, 78, 153-159.

Jacobsen, J.B.E. and McCarthy, T.S., 1976. An unusual hydrothermal copper deposit at Messina, South Africa. Economic Geology, 71, 117-130.

Jana, D. and Walker, D., 1997. The influence of sulphur on partitioning of siderophile elements: Geochimica et Cosmochimica Acta, 61, 5255-5277.

Kisters, A.F.M., Charlesworth, E.G., Gibson, R.L., and Anhaeusser, C.R., 1996. The relationship between antiformal and monoclinal steep structures in the O'okiep Copper District, Namaqualand: a case study. South African Journal of Geology, 99, 185-195.

Lombaard, A.F. and Schreuder, F.J.G., 1978. Distribution pattern and general geological features of steep structures, megabreccias and basic rocks in the O'okiep Copper District. In: Verwoerd WJ (ed.) Mineralization in metamorphic terranes. Special Publication of the Geological Society of South Africa, 4, 269-295.

Lombaard, A.F. and the Exploration Department staff of the O'okiep Copper Company Ltd., 1986. The copper deposits of the O'okiep Copper District. In: C.R. Anhaeusser and S. Maske (Editors), Mineral deposits of Southern Africa. Geological Society of South Africa, 1421-1445.

Maier, W.D., 2000. Platinum-group elements in Cu-sulphide ores at Carolusberg and East O'okiep, Namaqualand, South Africa. Mineralium Deposita, 35, 422-429.

Maier, W.D. and Barnes, S.-J., 1996. Unusually high concentrations of magnetite at Caraiba and other Cu-sulphide deposits in the Curaça valley, Bahia, Brazil. Canadian Mineralogist 34, 717-731.

Maier, W.D. and Barnes, S.-J., 1999. The origin of Cu sulphide deposits in the Curaca Valley, Bahia, Brazil: Evidence from $\mathrm{Cu}, \mathrm{Ni}, \mathrm{Se}$, and platinumgroup element concentrations. Economic Geology, 94, 165-183.

Maier, W.D. and Barnes, S.-J., 2004. Pt/Pd and Pd/Ir ratios in mantle-derived magmas: a possible role for mantle metasomatism. South African Journal of Geology, 107, 333-340.

Maier, W.D., Peltonen, P., McDonald, I., Barnes, S.J., Barnes, S.-J., Hatton, C. and Viljoen, F., 2011. The concentration of platinum-group elements and gold in southern African and Karelian kimberlite-hosted mantle xenoliths: Implications for the noble metal content of the Earth's mantle. Chemical Geology, 302-303 (2012), 119-135.

Marsh, J.S., Ewart, A., Milner, S.C., Duncan, A.R. and Miller, R.M., 2001. The Etendeka igneous province: magma types and their stratigraphic distribution with implications for the evolution of the Parana-Etendeka flood basalt province. Bulletin of Volcanology, 62, 464-486.

McIver, J.R., McCarthy, T.S. and Packham, B. de V., 1983. The copper-bearing basic rocks of Namaqualand, South Africa. Mineralium Deposita, 18, 135-160.

Minnitt, R.C.A., 1986. Porphyry copper-molybdenum mineralization at Haib River, South West Africa/Namibia. In: C.R. Anhaeusser and S. Maske (Editors), Mineral Deposits of Southern Africa. Geological Society of South Africa, 1567-1585.

Mungall, J.E., Hanley, J.J., Arndt, N.T. and Debecdelievre, A., 2006. Evidence from meimechites and other low-degree mantle melts for redox controls on mantle-crust fractionation of platinum-group elements, Proceedings of the National Academy of Science, 103, 12695-12700.

Naldrett, A.J., 1989. Sulphide melts - crystallization temperatures, solubilities in silicate melts, and $\mathrm{Fe}, \mathrm{Ni}$, and $\mathrm{Cu}$ partitioning between basaltic magmas and olivine. In: J.A. Whitney and A.J. Naldrett (Editors), Ore deposits associated with magmas, Reviews in Economic Geology, 4, 5-20.

Naldrett, A.J., Innes, D.G., Sowa, J. and Gorton, M.P., 1982. Compositional variation within and between five Sudbury ore types. Economic Geology, 77, 1519-1534.

Oliveira, E.P. and Tarney, J., 1995. Genesis of the Precambrian Cu-rich Caraiba hypersthenite-norite complex, Brazil: Mineralium Deposita, 30, 351-373.

Potgieter, J.E., 1996. Exploration in the O'okiep Copper District, Northern Cape Province, South Africa: an overview. South African Journal of Geology, 99, 209-220.

Read, D., Jarvis, N.V., Williams, T., Knoper, M. and Andreoli, M.A.G., 2002. The degradation of monazite: implications for the mobility of rare-earth and actinide elements during low-temperature alteration. European Journal of Mineralogy, 14, 487-498.

Robb, L.J., Armstrong, R.A. and Waters, D.J., 1999. The history of granulitefacies metamorphism and crustal growth from single-zircon U-Pb geochronology: Namaqualand, South Africa. Journal of Petrology, 40, 1747-1770.

Schoch, A.E. and Conradie, C.A., 1990. Petrochemical and mineralogical relationships in the Koperberg Suite, Namaqualand, South Africa. American Mineralogist, 75, 27-36.

Stumpl E.F., Clifford T.N., Burger A.J., Zyl V (1976) The copper deposits of the O'Okiep district, South Africa: new data and concepts: Mineral Deposita $11,46-70$

Sun, S.-S. and McDonough, W.F., 1989. Chemical and isotopic systematics of oceanic basalts: implications for mantle composition and processes. In: A.D. Saunders and M.J. Norry (Editors), Magmatism in the Ocean Basins, Geological Society, Special Publication 42, 313-345. 
Taylor, E., 1990. The geology and Ni-metallogenesis in the Namaqualaand Movile Belt, Kliprand, North-West Cape, South Africa. Unpublished BSc. (Honours) Project, University of the Witwatersrand, South Africa, 69pp.

Van Zwieten, A.J.M., McCarthy, T.S. and Cawthorn, R.G., 1996. A petrogenetic model for the Koperberg Suite: evidence from the Jubilee Mine, Namaqualand, South Africa. South African Journal of Geology, 99, 121-134

Von Gehlen, K., Nielsen, H., Rozendaal, A. and Jensen, M.L., 1990. Sulfur isotopes indicate a homogenous, probably mantle source for the O'okiep copper ores, Namaqualand. Abstract Geocongress ‘90, Geological Society of South Africa, Cape Town, 582-585.
Watkeys, M.K., 1996. The Klondike steep structure, O'okiep Copper District, South Africa. South African Journal of Geology, 99, 169-183.

Woodland, S.J., Pearson, D.G. and Thirlwall, M.F., 2002. A platinum-group element and Re-Os isotope investigation of siderophile element recycling in subduction zones: comparison of Grenada, Lesser Antilles Arc, and the Izu-Bonin Arc. Journal of Petrology., 43, 121-198.

Editorial handling: S. Prevec. 